\title{
スリップキャスト用アルミナ鋳込み型の開発
}

\author{
近藤直樹 · 田邊恵介 · 日向秀樹 · 長岡孝明 · 北 英紀 \\ 産業技術総合研究所 先進製造プロセス研究部門，干463-8560 名古屋市守山区下志段味穴ヶ洞2266-98
}

\section{Development of alumina mold for slip-casting}

\author{
Naoki KONDO, ${ }^{\dagger}$ Keisuke TANABE, Hideki HYUGA, Takaaki NAGAOKA and Hideki KITA \\ Advanced Manufacturing Research Institute, National Institute of Advanced Industrial Science and Technology (AIST), Shimo- \\ shidami 2266-98, Moriyama-ku, Nagoya 463-8560
}

\begin{abstract}
Slip-casting is widely used as one of the shaping methods of ceramics. Gypsum molds used for slip-casting are expendables, and industrial wastes after use. In this work, we attempted to develop alumina mold, which are used as substitute for the gypsum molds. Alumina mold also have heat resistance, therefore, it is applicable for a new manufacturing process, where alumina mold and slip-casted green body are fired together without de-molding. Here, we introduce ceramic mold and sintered alumina bodies made by using the mold.

(C) 2010 The Ceramic Society of Japan. All rights reserved.
\end{abstract}

Key-words : Alumina mold, Slip casting, Near-net shape, Firing

[Received October 26, 2009; Accepted January 15, 2010]

\section{1. 緒言}

鋳込み成形法（スリップキャスト法）は，セラミックス製 造によく用いられるプロセスの 1 つである. セラミック粉末 を高濃度に分散させたスラリーを石亳型に流し込み，スラ リー中の水分を石膏型に吸収, 粉末を固化させることにより 成形体を得ることができる。この際用いられる石膏型は, 型 取りが容易, 吸水性が良い, 離型性が良い, 等の鋳込久成形 用として優れた特性を有している ${ }^{1)}$ 。一方で, 石膏型は消耗 品であり, 繰り返し使用により寸法精度や脱型性が低下する ため, 15〜 100回程度の使用で廃棄される. 陶磁器用の型とし て使用された廃石亳は，6〜 7 割が再利用され, 残り（1999年 で約8500トンと推定）は産業廃棄物として埋め立て処分され ている ${ }^{2)}$. 昨今の処分場不足のため, 埋め立て処分量の削減 が求められている.

そこで, 本研究では, 石膏型に替わる鋳込久型として用い ることができるセラミックス型を開発することとした．これ までにも同用途のセラミックス型は提案されているため ${ }^{3)}$, ここでは単純な鋳込み型としてではなく, セラミックス型の 特徵, すなわち耐熱性に優れる点を活かし, セラミックス型 にスラリーを鋳込み, 固化させて成形体を得た後, 成形体を 型から脱型することなく型ごと焼成する，という新しいセラ ミックスの製造プロセスを含めて提案することとした。この 方法により, 成形体を型と同時にハンドリングすることが可 能となることから, バインダー量の削減やハンドリング困難 な大型品・薄肉品製造への適用が期待できる.

\footnotetext{
† Corresponding author: N. Kondo; E-mail: naoki-kondo@aist.go. jp
}

\section{2. 開発方針と性能評価}

型の開発は以下の方針に基づき，進めることとした.

1）型は低コストで汎用性の高いものとする.よって，こ こではアルミナをべース材とし，粗大アルミナと微細アルミ ナの粒度配合を抢こなうことによって, 気孔率を調整し, か つ，焼結による寸法変化を抑制することとした。

2) 型の形状化方法は, 石膏に近いものとする. よって, ここでは上記アルミナに少量のアルミナセメントと水を加え 混練した後, 流し込みにより型取りすることとした. 型は固 化後に焼成をおこなうことで, 鋳込み型として使用可能とな る.

3）型を用いて製造する製品は，アルミナを想定すること とした.アルミナは酸化物系セラミックスのうちで最も汎用 性の高いものであり, 焼成温度も $1600^{\circ} \mathrm{C}$ 近辺と高めである. この温度域での使用可能性を検証しておけば，より低温で焼 成する陶磁器等にも使用可能となる.

型としての性能評価は以下の観点でおこなった.

1）石膏型とアルミナ型の比較をおこなった．それぞれの 型について組織, 表面, 濡れ性を検証し, また, 型を用いて 作成した製品表面観察を抢こない，アルミナ型を用いた場合 でも，石膏型を用いた場合と同等の製品が得られることを検 証した.

2）アルミナ型の特徵を活かすための性能の検証をおこな った.すなわち, セラミックスを鋳込み型として使用し, 成 形体と型を同時に焼成する，というプロセスを取る場合，

i）吸水性：石膏同等の吸水性，成形性を有する.

ii）離型性 : 焼成後, 型から容易に取り出せる.

iii） 寸法安定性：焼成温度まで加熱しても, 型が变形し ない。

iv） 耐久性 : 型の繰り返しの使用が可能. 


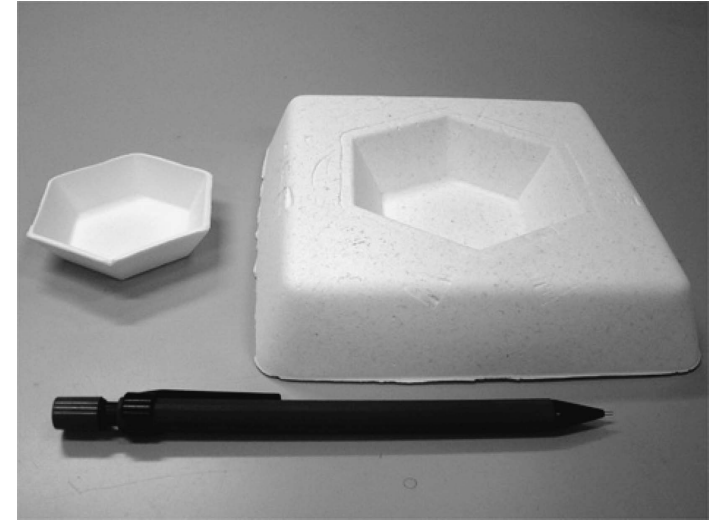

Fig. 1. Alumina mold (right) and sintered alumina (left).

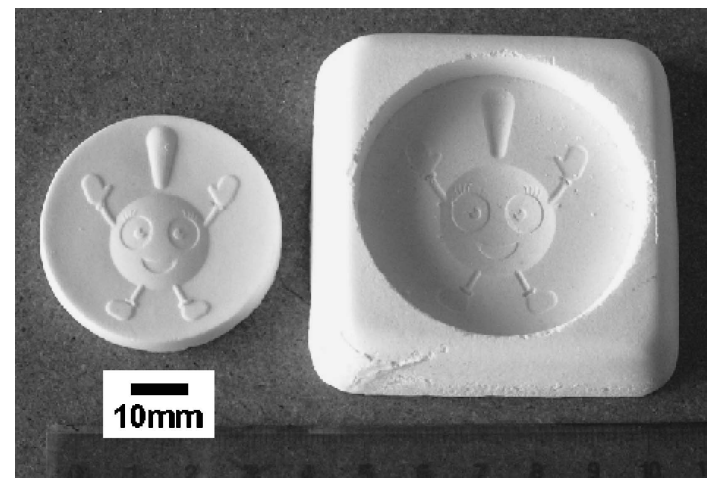

Fig. 2. Alumina mold (right) and sintered alumina (left).

の4 項目を満たすことが必要である.この 4 項目について繰 り返し使用を想定した試験をおこない, 性能評価をおこなっ た。

\section{3. 結果と考察}

\section{1 アルミナ型の作成}

原料として, サブミクロン〜 $150 \mu \mathrm{m}$ まで粒度の異なる数種 類の微細粒アルミナと $150 \mu \mathrm{m} \sim 2 \mathrm{~mm}$ 以下の粗大粒電融アル ミナを配合した．微細粒アルミナと粗大粒アルミナの配合重 量比は $1: 1$ を目安とした。この配合は, 粗大粒が骨格をつく り高温焼成時の焼結収縮を抑制, 微細粒がその隙間を埋めて 鋳込久可能な滑らかな表面をつくる, 適度な気孔率をもたせ ることで吸水性を実現する，という効果を狙ったものであ る.

上記混合原料に少量のアルミナセメントと水を加え混練し た後, 流し込みにより型取りした。. 固化, 乾燥ののち, 1600 ${ }^{\circ} \mathrm{C}$ にて 2 時間の焼成をおこない，使用型を作成した。作成し た型の例を Fig. 1 および Fig. 2 に示す。それぞれ右側がアル ミナ製鋳込久型の写真である. 特に Fig. 2では型取りを抢こ なった元型表面の模様が転写できている.

\section{2 石亳型とアルミナ型の比較}

上記で作成したアルミナ型と比較用の石膏型について, 気 孔率, 気孔径分布, 組織, 濡孔性を調査し, 比較を抢こなっ
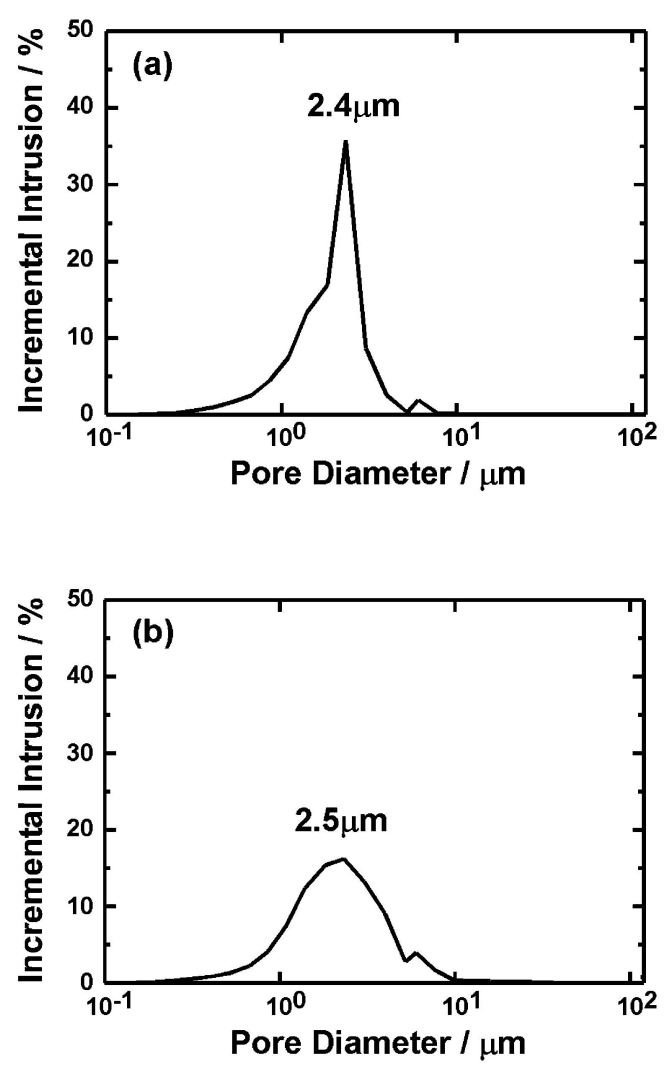

Fig. 3. Pore size distributions of (a) gypsum and (b) alumina molds measured by mercury porosimetry.

た。

水銀圧入法により気孔径分布を測定した結果を Fig. 3 に示 す，石亳型とアルミナ型の気孔率はそれぞれ $63 \%$ と $30 \%$ であ り，石膏型のほうがよりシャープな気孔径分布のピークを有 していた. 平均気孔径は $2.4 \mu \mathrm{m}$ と $2.5 \mu \mathrm{m}$, 最小径は $0.12 \mu \mathrm{m}$ と0.15 $\mu \mathrm{m}$ と, ほぼ同じであり, 最大径は $7.7 \mu \mathrm{m}$ と $12.6 \mu \mathrm{m}$ でややアルミナ型のほうが大きくなっていた.

石膏型とアルミナ型の表面組織を走査型電子顕微鏡（Scanning Electron Microscope, SEM) により観察した。結果をFig. 4(a) および Fig. 5 (a)に示す. 石亳型表面は, 針状の結晶が絡 久合った組織となっており, 針状結晶のすきまに気孔が存在 していた. 一方, アルミナ型表面では, アルミナ粒子が部分 焼結（ネッキング）した組織となって抢り，アルミナ粒子の すきまに気孔が存在していた. 加えて, 微細なクラックが観 察できた.

石亳型は難濡れ性（蹯水性）を有することが，鋳込久成形 に有利であるとされている ${ }^{1)}$. 難濡れ性により, 石膏型表面 の微細気孔へのスラリー進入が妨げられ, 良好な離型性を示 す. もし, 表面気孔にスラリーが進入すると, アンカー効果 により成形体の離型が困難になり，また，目詰まりを抢こし て吸水性の低下につながる. そこで, ポリカルボン酸アンモ ニウム塩を分散剂に用いて鋳込み用に調整したアルミナスラ リー（純度 $99.5 \%$ ）を用いて型への接触角を調べた. 石亳型 へのスラリーの接触角が 119 度であるのに対し, アルミナ型で は105度であり，アルミナ型のほうが難濡れ性に劣っていた。 これは,アルミナ粉末をスラリー化する祭に加えた分散剤 

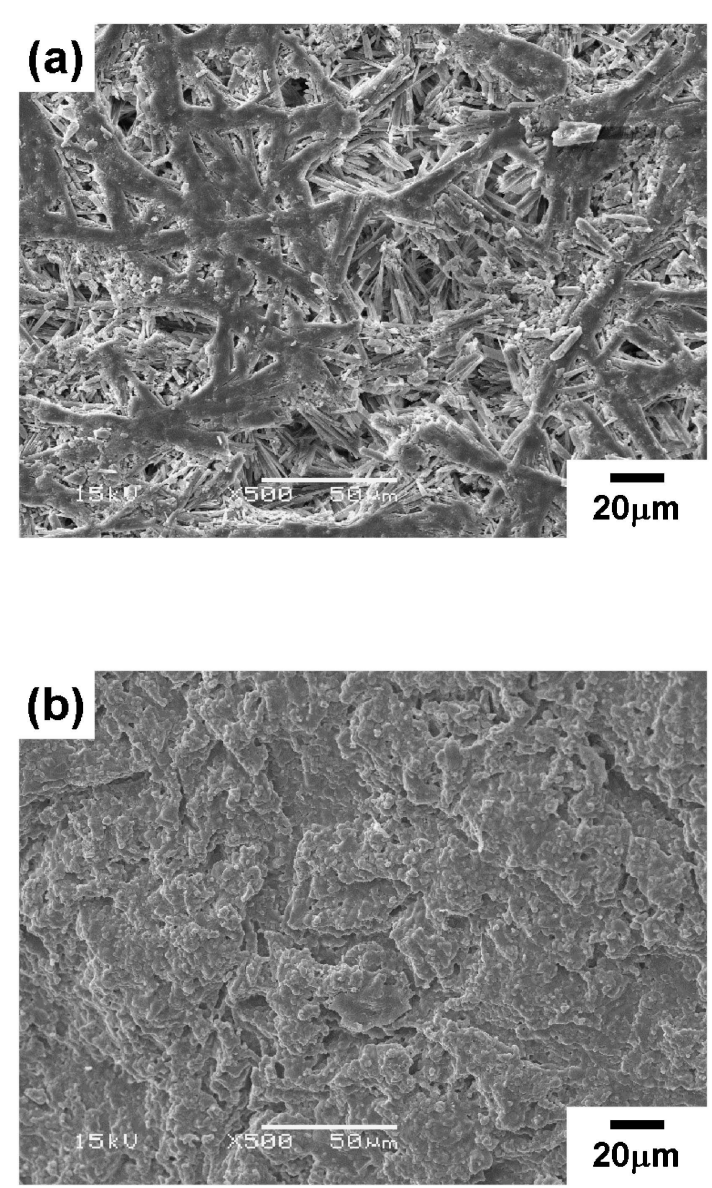

Fig. 4. Surface structures of (a) gypsum mold and (b) sintered alumina.

Sintered alumina was slip-casted into gypsum mold, followed by demolding and sintering.

が，同種材料であるアルミナ型にも作用して，濡れ性を低下 させたものと考えられる. そこで, 難濡れ性向上と離型性を 実現する離型剂の使用を検討した，今回開発したアルミナ型 は, 成形体と同時に焼成するため, 焼成時に燃焼し灰分が残 らない疎水性ポリマーを選定し, アルミナ型表面へ塗布した 後, 接触角を測定したところ, 143度へと難濡れ性が大幅に向 上した.

\section{3 アルミナ型の性能検証}

作成したアルミナ型を用いて，今回提案する「セラミック ス型にスラリーを鋳込み, 固化させて成形体を得た後, 成形 体を型から脱型することなく型ごと焼成する」という製造プ ロセスの可能性を検証した.

離型剂を塗布した型に, 前述したアルミナスラリーを流し 込及, 着肉後に排泥, 乾燥させた後, 脱型なしで型ごと 1600 ${ }^{\circ} \mathrm{C} 2 \mathrm{~h}$ の焼成を抢こなった。 得られたアルミナ焼結体の例を Fig. 1 および Fig. 2 に示す. それぞれ左側が焼結体の写真で ある. Fig. 1 では 1 辺の長さ $3 \mathrm{~cm}$, 厚み $1.5 \mathrm{~mm}$ の焼結体が 得られた. Fig. 2 では型表面の模様が転写できた $0.7 \mathrm{~mm}$ の薄 肉焼結体を得ることができた。

得られた焼結体の表面を, 石膏型を用いる通常プロセスで
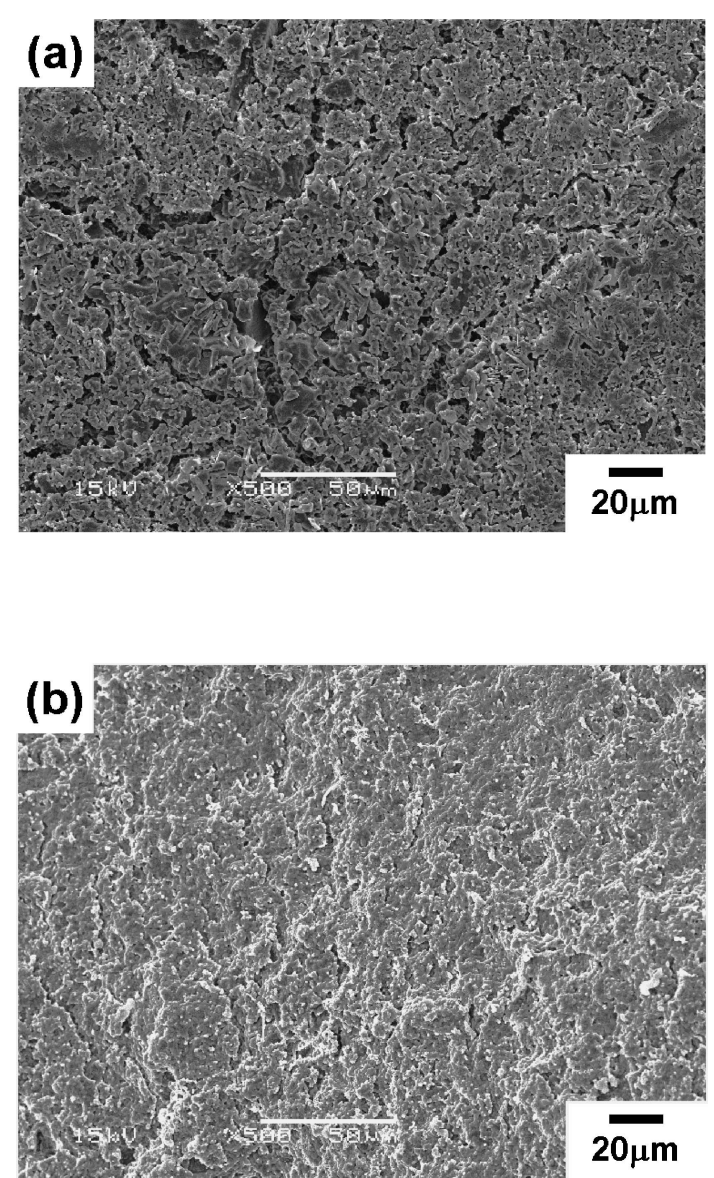

Fig. 5. Surface structures of (a) alumina mold and (b) sintered alumina.

Sintered alumina was slip-casted into alumina mold, followed by sintering without de-molding.

作成した焼結体表面と比較した. 結果を Fig. 4(b) および Fig. 5(b)に示す.SEM 観察によれば，焼成面の粗さは同程度であ った.アルミナ型を用い, 脱型なしで型ごと焼成した場合で も，石膏型を用いた場合と同等の製品が得られることが確認 できた.

鋳込み成形の着肉時に吸水性の問題はみられなかった。着 肉はスラリー中の水分が型に吸収され, 流動性を失った粉末 が型内面に堆積する, というフィルタープロセスで進行す る. 石膏型の場合, 水の流動抵抗は着肉層内のほうが石膏内 より高く, 着肉速度は初期を除き着肉層内の水の流動抵抗に よって決まる, とされている1). アルミナ型の場合, 石亳型 に比べて気孔率は低いが, 同様の理由で吸水性に問題がなか ったものと考えられる.

石膏型を鋳込み成形に使用する際, 成形体が石膏型由来の カルシウム $(\mathrm{Ca})$ により污染されることがある. 今回作成し た型には，アルミナセメントの成分值と配合量より概算する と, $\mathrm{CaO}$ は 1.7 重量 $\%, \mathrm{SiO}_{2}$ は 0.2 重量 $\%, \mathrm{TiO}_{2}$ は 0.01 重量 $\%, \mathrm{MgO}$ や $\mathrm{Fe}_{2} \mathrm{O}_{3}$ はそれ以下，が含まれる。そこで， $\mathrm{Ca}$ 注目し,この型を用いて焼成したアルミナ表面の走査型電子 顕微鏡一エネルギー分散型 $\mathrm{X}$ 線分析 (Scanning Electron Microscopy-Energy Dispersive Spectroscopy, SEM-EDS) 測定 をおこなったが，Caの污染は検出されなかった。ただし， 

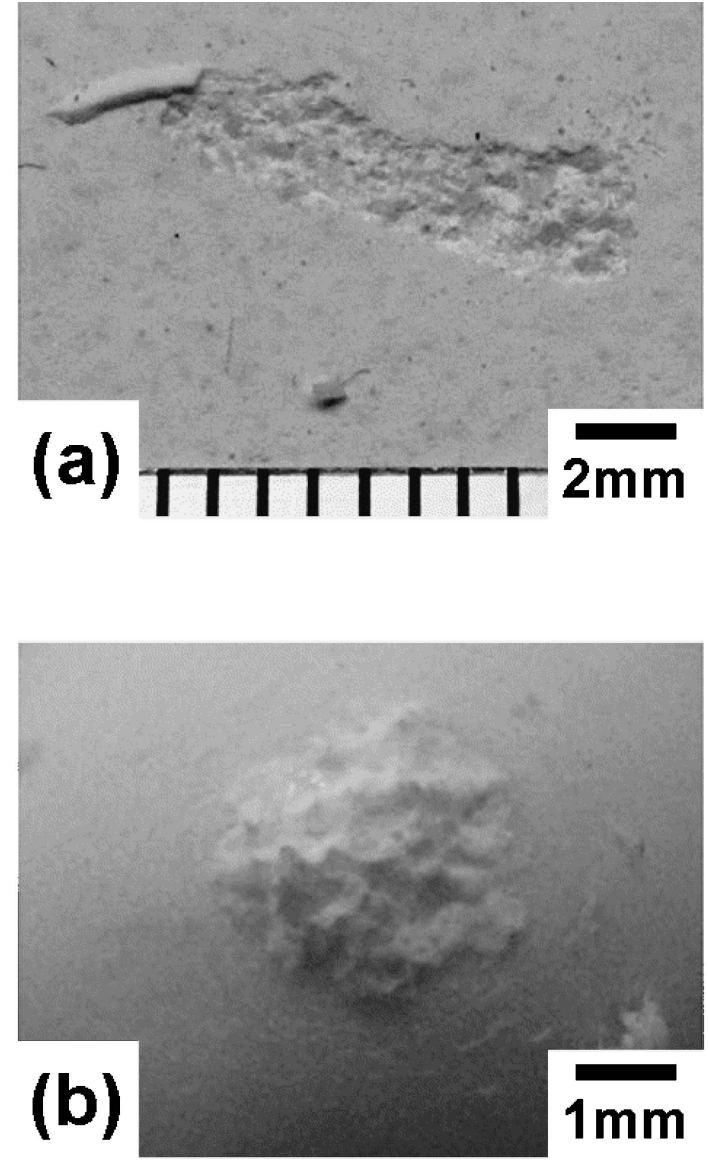

Fig. 6. (a) Damaged mold surface and (b) stuck on sintered alumina surface. Here, de-molding agent was not used for slip-casting.

EDS の検出限界が $0.2 \%$ 程度となるため, より微量の Ca 污染 は別手法での検証が必要となる. 石亳型からの Ca 污染は, 石膏からの溶出によるものと石亳型の磨耗による付着が原因 とされる. 今回作成した型は, アルミナを主成分とし, か つ，焼成を抗なうことで粒子間の結合が強固となっている ため, $\mathrm{Ca}$ の溶出は抢こりにくく, 磨耗も少ないため, $\mathrm{Ca} の$ 污染防止には有利であると考えられる.

ここで, 離型剤の効果を示す。上述の例は離型剤を使用し ているが, 使用しなかった場合, Fig. 6 に示すような, 焼結 体への型の焼きつきと型の破損が頻発した．離型剂を使用す ることにより，このような焼きつきを防止できた．離型剤を 使用しなかった場合, 型表面の粗大気孔あるいはクラックに スラリーが進入して成形体が固着し, 焼成後の焼きつきにつ ながったものと考えられる。離型剤には, 塗布することによ り, スラリーの進入を防止し, 焼成後の離型を容易にする効 果が期待できる.

型の繰り返し使用可能性を検証するため, 鋳込みと $1600^{\circ} \mathrm{C}$ $2 \mathrm{~h}$ の焼成を20回あまり抗こなった。この繰り返し後も, 作 成直後と同様にアルミナ焼結体を得ることができた.

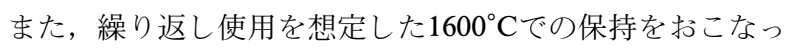
て, 型の寸法変化と表面状態の変化を観察した. 寸法変化を Fig. 7 に示す.ここでは作成直後の状態を基準として示して ある. 使用型作成時の $1600^{\circ} \mathrm{C} 2 \mathrm{~h}$ の焼成により, 型取りした

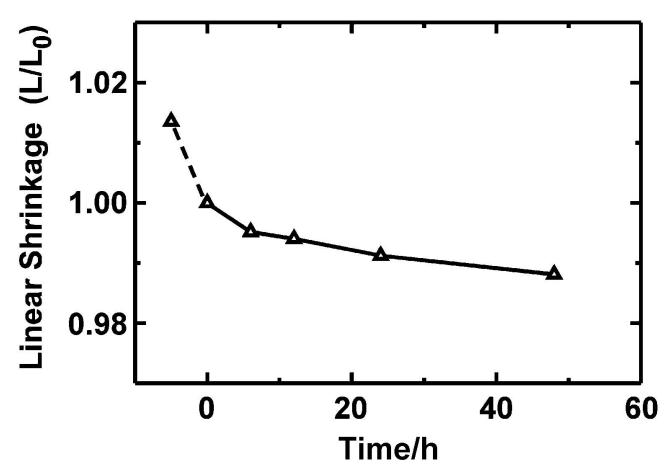

Fig. 7. Linear shrinkage of the alumina mold during soaking at $1600^{\circ} \mathrm{C}$.
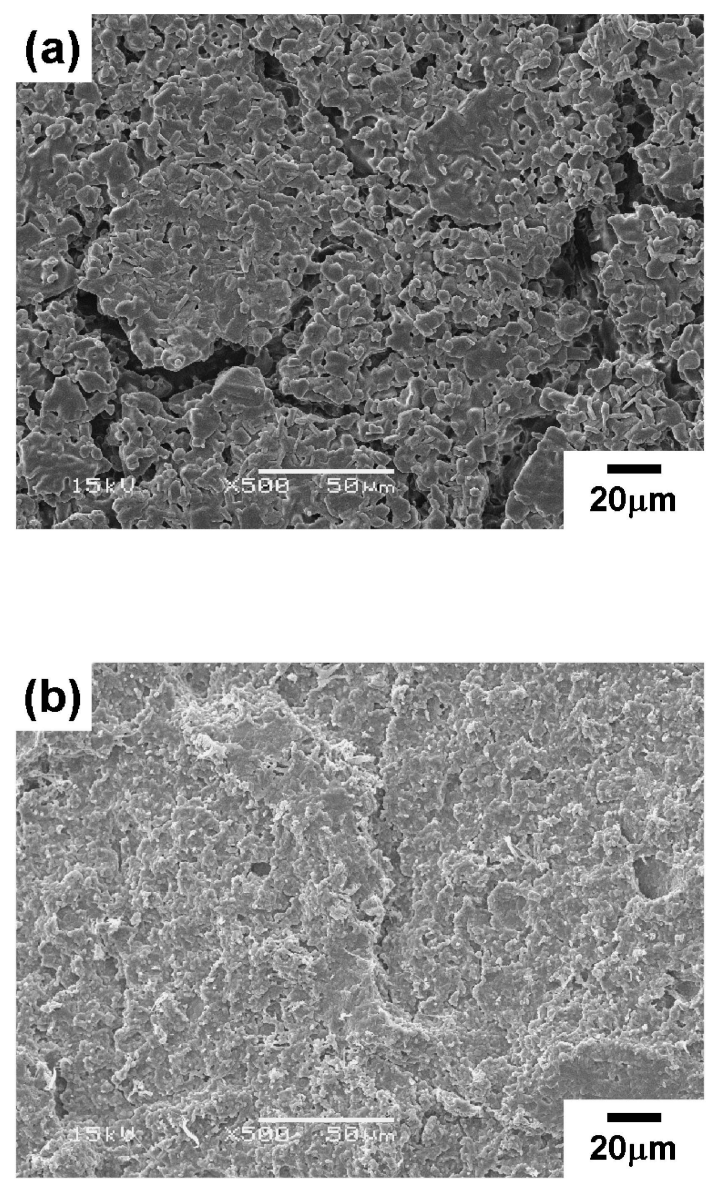

Fig. 8. Surface structures of (a) alumina mold after soaking at $1600^{\circ} \mathrm{C}$ for $48 \mathrm{~h}$ and (b) sintered alumina fabricated by using the mold.

元型より $1.3 \%$ の線収縮がみられた。 また, $1600^{\circ} \mathrm{C} 48 \mathrm{~h}$ の保 持後には, 使用型より $1.2 \%$ の収縮がみられた。 その表面を Fig. 8 (a) に示す。初期にみられた Fig. 5 (a) に示すような微細 なクラックが高温保持により拡大していた. 型の焼結が進行 し，クラック拡大につながったものと考えられる.

$1600^{\circ} \mathrm{C} 48$ 時間保持後の型を用いてアルミナ焼結体を作成し た. 保持後も，作成直後と同様にアルミナ焼結体を得ること 
ができた. 得られた焼結体の表面状態を観察した結果, Fig. 8(b)に示すように, 一部に型表面のクラックの転写が疑われ る高さ数 $\mu \mathrm{m}$ の段差が観察された.この段差は, 焼結体全体 に対しては微細なものである.これを除き, 全般に初期の型 を用いて作成した焼結体と大きな差はみられず，この型は繰 り返し使用に耐えうるものといえる.

本手法を広く応用するためには, 他の材料への適用につい て検討する必要がある. 特に, 焼成時にガラス等の液相成分 を大量に生じる材料や，アルミナ型と反応しやすい成分を含 む材料では, 張り付きや反応などの問題が生じる可能性があ ると予想される。これまでに, 液相成分を含む例として, 今 回の型およびプロセスにより, シリカ 5 重量\%およびマグネ シア 3 重量\%を含む液相焼結アルミナの作成が可能であるこ とを確認してある. 今後, より多くの液相成分を含む例や反 応性に富む成分を含む例での検証が必要である.

\section{4. まとめ}

（1）アルミナ製鋳込久型を作成するとともに，型が耐熱性 に優れるという特長を活かし, 型にスラリーを鋳込み, 固化 させて成形体を得た後, 成形体を脱型することなく型ごと焼 成する, という新しいセラミックスの製造プロセスを提案し た.

（2）上記方法により，アルミナ焼結体を得ることができ
た.

（3）アルミナ型の性能評価とそれを用いて作成したアルミ ナ焼結体の評価を抢こない, 石亳型を用いた場合と比較し た. 結果, アルミナ型を用いる場合でも石膏型と同等のアル ミナ焼結体を得ることができることがわかった．

（4）離型剂を使用しない場合, 型への焼き付きが頻発した が, 焼成時に消失する離型剤を使用することで問題解決でき た.

（5）鋳込みにより作成した成形体を型と同時にハンドリン グすることが可能となることから, バインダー量の削減や八 ンドリング困難な大型品・薄肉品製造への適用が期待でき る.

謝辞 本研究は, 文部科学省都市エリア産学官連携促進事 業「環境調和性成形型及び製品化技術の開発-非石膏型によるプ レス・鋳込み成形量産システムの開発」として行われた.

\section{References}

1) "Ceramics Processing -Powder Preparation and Forming-," The Ceramic Society of Japan (1984) pp. 158-159.

2) SAN-ESU GYPSUM CO., LTD., http://www.san-esugypsum. co.jp/hurugata.html.

3) Y. Kondo, Y. Hashizuka, M. Nakahara and K. Yokota, J. Ceram. Soc. Japan, 101, 928-931 (1993). 